\title{
Application of polychaetes in (de)coupled integrated aquaculture: an approach for fish waste bioremediation
}

\author{
Marit A. J. Nederlof ${ }^{1, *}$, Jinghui Fang ${ }^{2,3}$, Thomas G. Dahlgren ${ }^{4,5}$, \\ Samuel P. S. Rastrick ${ }^{6}$, Aad C. Smaal ${ }^{1,7}$, Øivind Strand ${ }^{6}{ }^{6}$ Harald Sveier ${ }^{8}$, \\ Marc C. J. Verdegem ${ }^{1}$, Henrice M. Jansen ${ }^{6,7}$ \\ ${ }^{1}$ Aquaculture \& Fisheries Group, Wageningen University, 6708 WD Wageningen, The Netherlands \\ ${ }^{2}$ Key Laboratory for Sustainable Utilization of Marine Fisheries Resources, Ministry of Agriculture, \\ Yellow Sea Fisheries Research Institute, Qingdao 266071, PR China \\ ${ }^{3}$ Laboratory for Marine Fisheries Science and Food Production Processes, \\ Pilot National Laboratory for Marine Science and Technology (Qingdao), Qingdao 266237, PR China \\ ${ }^{4}$ NORCE, Norwegian Research Centre, 5006 Bergen, Norway \\ ${ }^{5}$ Gothenburg Global Biodiversity Centre, Department of Marine Sciences, University of Gothenburg, 41319 Gothenburg, \\ Sweden \\ ${ }^{6}$ Institute of Marine Research, 5005 Bergen, Norway \\ ${ }^{7}$ Wageningen Marine Research, 4401 NT Yerseke, The Netherlands \\ ${ }^{8}$ Lerøy Seafood Group, 5020 Bergen, Norway
}

\begin{abstract}
Development of benthic components within integrated multi-trophic aquaculture (IMTA) systems warrants more attention, and the development of polychaetes as an extractive component in IMTA systems is ongoing. This study estimates the bioremediation potential of Capitella sp. and Ophryotrocha craigsmithi for coupled and decoupled salmon-driven IMTA. In coupled IMTA, polychaetes receive fresh faeces, while in decoupled IMTA, preservation of faeces is applied. Respiration and ammonia excretion rates were measured for polychaetes fed fresh, oven-dried or acidified salmon faeces, and combined with nutrients incorporated into tissue growth, to estimate nutrient requirements. Nutrient requirements were subsequently used to evaluate bioremediation potential. Metabolic rates were highest for $O$. craigsmithi and contributed notably to their overall nutrient requirement (20-30\%). For the 2 polychaete species, nutrient requirements ranged from 5 to $26 \mathrm{mg} \mathrm{C}$ and from 2 to $6 \mathrm{mg} \mathrm{N} \mathrm{g}^{-1}$ AFDW d $\mathrm{m}^{-1}$. These requirements were comparable with or higher than other polychaete species, highlighting the potential for fish waste bioremediation by Capitella sp. and O. craigsmithi. Preserved diets reduced bioremediation potential 1.5 and 3-5 times for, respectively, Capitella sp. and O. craigsmithi. Assuming that polychaetes are efficient fish-faeces convertors, the bioremediation potential indicates that benthic cultivation units containing 65000-95000 ind. $\mathrm{m}^{-2}$ of Capitella sp. or 36 000-194 000 ind. $\mathrm{m}^{-2}$ of $O$. craigsmithi can convert the daily organic waste flux deposited below an average salmon farm. These densities were within ranges reported for wild populations, indicating that, based on the bioremediation potential, development of benthic IMTA with these 2 polychaete species seems realistic and efficient for waste conversion.
\end{abstract}

KEY WORDS: Metabolic processes · Ophryotrocha craigsmithi $\cdot$ Capitella sp. $\cdot$ Benthic IMTA · Integrated multi-trophic aquaculture $\cdot$ Deposit feeders $\cdot$ Sustainability 


\section{INTRODUCTION}

Sustainability issues in aquaculture have fuelled interest in integrated multi-trophic aquaculture (IMTA) systems. In IMTA systems, fed cultures (e.g. fish) are coupled with extractive cultures in such a way that waste resulting from the fed cultures (i.e. uneaten feed, faeces and metabolic excreta) serve as a nutrient source for algae or invertebrates. Due to the potential to reduce aquaculture waste while generating a valuable crop, IMTA is considered to be sustainable (Chopin 2015, Hughes \& Black 2016). The concept of IMTA has developed over the years (Chopin 2013, Hughes \& Black 2016), and alternative concepts have been presented, including coupled and decoupled integrated systems (Goddek et al. 2016, Jansen et al. 2019). While coupled IMTA refers to the more conventional approach whereby extractive species are integrated in proximity of the fed species, in decoupled IMTA, the different compartments (i.e. fed species and extractive species) are integrated as separate functional units. Spatial connection between the cultivation units is not required in decoupled integrated aquaculture (Goddek et al. 2016).

One of the ecological concerns of finfish aquaculture is the impact of solid wastes on the benthic ecosystem (Taranger et al. 2015, Quiñones et al. 2019). Nonetheless, research on benthic species in IMTA has received less attention than species in the water column (Granada et al. 2016, Filgueira et al. 2017, Jansen et al. 2019, Strand et al. 2019). Deposit-feeding polychaetes have been suggested as potential candidates for benthic IMTA (e.g. Bischoff et al. 2009, Bergström et al. 2015, Gómez et al. 2019, Jansen et al. 2019) and several studies have quantified their bioremediation potential, reporting removal efficiencies ranging from 20 to $85 \%$ for organic matter (OM), 65 to $91 \%$ for organic C, and 31 to $91 \%$ for organic N (Honda \& Kikuchi 2002, Palmer 2010, Fang et al. 2016a, Marques et al. 2017, Pajand et al. 2017, Gómez et al. 2019). In the field, it has been demonstrated that the opportunistic polychaete species of the genus Capitella Blainville, 1828, which thrives under eutrophic conditions, is able to significantly reduce OM in sediments underneath cage farms and in pond systems (Tsutsumi et al. 2002, Kinoshita et al. 2008). These studies highlight the potential of polychaetes as extractive species in IMTA systems.

Underneath salmon farms, large densities of opportunistic polychaete species are naturally present (Kutti et al. 2007b, Wiklund et al. 2009b, Salvo et al. 2015b). Among these opportunistic species, Ca- pitella sp. and Ophryotrocha craigsmithi Wiklund, Glover \& Dahlgren, 2009 (see Wiklund et al. 2009a) have been identified (Kutti et al. 2007b, Bannister et al. 2014, Valdemarsen et al. 2015). In a recent study, Nederlof et al. (2019) showed that these species grow well on salmon faeces in laboratory trials, and highlighted that based on their nutritive quality, both species seem interesting as a high-quality marine ingredient for aquatic diets. Their ability to convert salmon faeces into valuable biomass shows that Capitella sp. and $O$. craigsmithi have potential as extractive species for cultivation in connection with Atlantic salmon Salmo salar. In addition, development of benthic cultivation methods for these polychaete species is ongoing (Jansen et al. 2019). Apart from increasing the productivity of a production system, the IMTA approach also strives to reduce wastes produced by fed species via extractive species (Chopin 2013, Hughes \& Black 2016). To fully understand the potential of Capitella sp. and O. craigsmithi as an extractive component in IMTA systems, their bioremediation potential should thus be studied.

Since the grow-out phase of salmon aquaculture is predominantly open-water cage culture, environmental concerns motivate an exploration of alternative production systems, such as enclosed or semienclosed sea cages where waste collection could be possible (Lekang et al. 2016). While deposit feeders cultivated underneath open-water cages (i.e. coupled integrated aquaculture) can directly feed on the fresh solid waste, (semi-)enclosed systems make it possible to collect and upgrade solid wastes before use (e.g. decoupled integrated aquaculture). In decoupled IMTA systems, preservation of the collected organic wastes is recommended, as fish waste degrades quickly (Beristain 2005). In the current study, 2 preservation techniques were chosen, drying and acidification. These methods are relatively fast and easy to apply, which makes commercial application more feasible. Both preservation methods may inactivate microbial activity and thereby reduce decomposition rates (Luckstadt 2008, Betoret et al. 2016). However, microbes may also contribute to the diets of O. craigsmithi and Capitella sp. (Fauchald \& Jumars 1979, Findlay \& Tenore 1982, Salvo et al. 2015a). Further, compositional changes of solid waste due to preservation potentially affects the nutritional value for the polychaetes, which is most likely to occur during preservation by acidification (Hardy et al. 1984, Özyurt et al. 2016).

The main objective of the present study was to estimate the bioremediation potential of Capitella sp. and $O$. craigsmithi fed fresh and preserved salmon 
faeces in order to evaluate their application in coupled and decoupled IMTA systems. Respiration and ammonia excretion rates measured in this study, combined with nutrients incorporated in tissue growth (based on data from Nederlof et al. 2019), were used as a proxy to estimate the nutrient requirements (i.e. absorbed nutrients) of the polychaetes. Based on high assimilation efficiencies (AE) reported in previous studies for polychaetes fed aquaculture waste (Honda \& Kikuchi 2002, Fang et al. 2016a,b), it can be assumed that the proxies used in this study serve as a valid indication for the nutrient requirements of the polychaetes. Nutrient requirements were subsequently related to deposition of fish waste as a proxy for the bioremediation potential of the 2 polychaete species studied. It should be noted that in this study, bioremediation potential includes recycling of organic waste nutrients by polychaete mineralization (i.e. metabolic processes) and nutrient incorporation in polychaete biomass, but excludes information on consumption and $\mathrm{AE}$, and thus on the amount of waste nutrients that remain in the system.

In addition to the main objective, whether metabolic rates differed when measured either on population or on individual scale was also investigated for both polychaetes. As metabolic rates can be affected by several drivers, the metabolic response of individuals may differ from the response of populations, as a population can be more than the sum of its parts (Hassall 1983). Measurements on a population scale provide information on what can be expected in the field (e.g. cultivation underneath salmon cages), whereas measurements on an individual scale facilitate an understanding of the underlying physiology. Ophrytorocha species 'cluster' naturally in dense colonies on organically enriched substrates forming polychaete-mucus complexes (Salvo et al. 2014). Capitella species are known to form dense patches in organic enriched sediments (Tsutsumi et al. 2002). It was hypothesized that formation of these polychaete-mucus complexes and dense polychaete patches may influence the maintenance of physiological processes, resulting in differences between measurements on population or individual scale.

\section{MATERIALS AND METHODS}

\subsection{Species collection}

Animals were collected underneath 2 different commercial Atlantic salmon Salmo salar farms located in the coastal area of western Norway. One farm was characterized by a soft bottom (125 m depth), where individuals of the genus Capitella were collected using a Van Veen grab. In this study, the name 'Capitella sp.' was used for the species investigated, since the species belonging to the genus Capitella occurring in Norwegian waters are morphologically similar (cryptic) and include currently undescribed species. A taxonomic revision of annelids in nutrient-rich habitats (e.g. underneath fish farms) in Norway, including Capitella species, is ongoing (T. G. Dahlgren unpubl. data). The substrate below the second salmon farm, where Ophryotrocha craigsmithi was collected, was characterized by a hard bottom (140 m depth). For this polychaete, which belongs to a genus of morphologically similar species (Wiklund et al. 2009a), species determination was confirmed using cytochrome $c$ oxidase subunit I (COI) barcode data (Hebert et al. 2003). For the collection of $O$. craigsmithi, 3 iron trays $(1.2 \times 1.2 \times$ $0.1 \mathrm{~m}$, with a perforated base to allow water to pass through), covered with different plastic substrates, were placed underneath the fish farm. The trays were deployed at depths varying between 50 and $150 \mathrm{~m}$, and were left submerged for $3 \mathrm{wk}$. After $3 \mathrm{wk}$, the trays were brought to the surface and polychaetes were collected. Both the Van Veen grab and benthic tray samples were carefully washed and polychaetes were collected. Collected polychaetes were immediately placed in an aerated tank containing seawater from $200 \mathrm{~m}$ depth, ensuring comparable salinity and water quality to their natural conditions. Then the polychaetes were transported to the experimental facilities of Austevoll Research Station (Institute of Marine Research, Norway), where the experiments were conducted.

\section{2. $\mathrm{C}$ and $\mathrm{N}$ mass balance}

Nutrient requirements ( $\mathrm{C}$ and $\mathrm{N}$ ) were estimated using a mass balance approach based on metabolic processes (measured as respiration and excretion) and nutrients incorporated into tissue growth. Mass balances were calculated for polychaetes fed fresh and preserved salmon faeces. Metabolic processes were measured and the experimental procedure is described below. Nutrients incorporated into tissue growth were calculated based on growth and tissue content data published in Nederlof et al. (2019), which includes a detailed description of how growth and tissue content data were obtained. It should be noted that the experiment described in the present study and the experiment described in Nederlof et al. 
(2019) were run in parallel, under comparable conditions and with the same dietary treatments, namely fresh, acidified and dried salmon faeces fed to the 2 polychaete species.

\subsubsection{Diet preparation and treatments}

Capitella sp. and O. craigsmithi were fed 3 different diets: fresh, acid-preserved and oven-dried faeces. To prepare the diets, faeces were collected twice a week by stripping salmon (individual weight: ca. 2-4 kg) kept at the sea cage facility of Austevoll Research Station. The collected faeces were directly centrifuged (6300 × $g$ for 3 min; Eppendorf 5810R), and liquid was carefully removed. This process was repeated twice. The remaining solid fraction was homogenized and used to formulate the experimental diets. For the fresh diet treatment, polychaetes were directly fed with fresh centrifuged faeces. For the acid diet treatment, centrifuged faeces were preserved by the addition of formic acid ( $80 \%)$, creating a $\mathrm{pH}<4(\mathrm{pH}: 3.4 \pm 0.1$ ), and left for $24 \mathrm{~h}$ at room temperature. Before feeding, excessive liquid was carefully removed and the faeces were washed twice with seawater to reduce acidity. For the washing procedure, seawater was added to the acidified faeces, which was then centrifuged $(6300 \times g$ for $3 \mathrm{~min}$; Eppendorf 5810R), and liquid was removed. For the oven-dried diet treatment, centrifuged faeces were preserved by oven-drying for $48 \mathrm{~h}$ at $100^{\circ} \mathrm{C}$, which is assumed to kill the majority of bacteria present in the faeces. Treatments were started on 3 successive days, as preservation of the diets needed different time spans, i.e. Day 1: fresh diet treatment (direct use), Day 2: acid diet treatment (24 h), and Day 3: oven-dried diet treatment (48 h). In total, polychaetes were fed the experimental diets for $2.5 \mathrm{wk}$.

Prior to the respiration and excretion measurements, animals were kept in $1 \mathrm{l}$ flow-through holding tanks (flow rate: $28 \pm 2 \mathrm{ml} \mathrm{min}^{-1}$ ), placed in the dark (ca. 50-70 ind. tank $\mathrm{k}^{-1}$ ). These tanks received filtered $(1 \mu \mathrm{m})$ seawater (salinity: $34.8 \pm 0.1$, temperature: 8.7 $\pm 0.2^{\circ} \mathrm{C}$ ) pumped from $200 \mathrm{~m}$ depth. These conditions were comparable to conditions measured underneath the salmon farms where the polychaetes were collected (conductivity, temperature and depth scans, data not shown). For Capitella sp., glass marbles (5 mm diameter, VWR Norway) were added to the tanks ( 1 $\mathrm{cm}$ of the bottom was covered), to mimic natural substrates while providing the opportunity to observe animals during daily check-ups. For $O$. craigsmithi, a pre-combusted (overnight, $550^{\circ} \mathrm{C}$ ) stone
( $\sim 5 \mathrm{~cm}$ width and length) was added to the tanks. The rough surface of the stone was assumed to mimic natural substrates for mucus attachment. Animals were fed the experimental diets for $2.5 \mathrm{wk}$ before respiration and ammonia excretion measurements were started by feeding them, in excess $(\sim 1.5 \mathrm{~g}$ chamber $^{-1}$ feeding $^{-1}$ ), fresh or preserved salmon faeces twice a week. Leftover feed was always observed, confirming that feed was provided in excess. During each feeding, feed samples were collected and stored in the freezer $\left(-20^{\circ} \mathrm{C}\right)$ before analyses.

\subsubsection{Respiration and ammonia excretion measurements}

Respiration and excretion were measured after animals were placed in clean tanks receiving filtered $(1 \mu \mathrm{m})$ seawater and were left for $2 \mathrm{~d}$ in order to defecate and empty their guts. The next day animals were transferred to the respiration chambers and measurements on metabolic rates started. Directly after the respiration and ammonia excretion measurements, polychaetes were sampled to determine their average weight (on an ash-free dry weight [AFDW] basis). For polychaetes fed fresh salmon faeces, respiration and excretion were measured at both individual and population scales. For polychaetes fed preserved diets, measurements were only done on a population scale. Respiration chambers consisted of closed chambers filled with filtered $(1 \mu \mathrm{m})$ seawater (salinity: $34.8 \pm 0.1, \mathrm{pH}: 7.9 \pm 0.1$ ). For $O$. craigsmithi, respiration chambers with a volume of 1 and $17 \mathrm{ml}$ for, respectively, measurements on individual scale ( $\mathrm{n}=1$ ind. chamber $^{-1}$ ) or what was defined as population scale ( $\mathrm{n}=10$ ind. chamber $^{-1}$ ) were used. Chamber volume for individuals of Capitella sp. was doubled $(2 \mathrm{ml})$, as these chambers included marbles to mimic natural substrates $(1 \mathrm{ml}$ of the respiration chamber was filled with marbles). Marbles were also added to the population-scale respiration chamber used for Capitella sp. (total volume of $17 \mathrm{ml}, 4 \mathrm{ml}$ was filled with marbles; $\mathrm{n}=13$ ind. chamber $^{-1}$ ). For individual measurements, average weight was $2.1 \pm 1.0$ and $1.2 \pm 0.6 \mathrm{mg}$ AFDW for Capitella sp. and $O$. craigsmithi respectively, and for population measurements, average individual weight was $1.8 \pm 0.7$ and $1.3 \pm 0.3 \mathrm{mg}$ AFDW for Capitella sp. and $O$. craigsmithi respectively. Population measurements were made with 8 repetitions per treatment (i.e. diet) per polychaete species, while there were 18 repetitions per species for the individual measurements. However, 3 individuals of $O$. craigsmithi died during 
the respiration and excretion measurements done on individual scale and were therefore excluded, resulting in a sample size of 15 for this species. For a summary of the experimental set-up, see Table 1.

Oxygen consumption rates were determined using an optical system as described by Rastrick \& Whiteley (2011). A PreSens ${ }^{\circledR} 10$-channel non-invasive oxygenanalysing system (PreSens ${ }^{\circledR}$ OXY-10) was used for the measurements. As preservation of the diets needed different time spans, treatments (i.e. fresh, acid and dried) were run independently per polychaete species. Each population run consisted of 8 experimental (i.e. replicates) and 1 control chamber (i.e. without polychaetes). Individual measurements were performed on the same day, with 2 runs of 9 experimental and 1 control chamber per polychaete species. Oxygen concentrations were logged every 15 s. Incubations were terminated when $\mathrm{O}_{2}$ concentrations in all chambers had decreased at least 20\%. All chambers showed a linear decrease in $\mathrm{pO}_{2}$ throughout the incubation period $\left(\mathrm{R}^{2}=0.6095-0.9963\right.$, min-max), showing that oxygen uptake was not affected by handling stress or by changes in oxygen saturation during the measurement period. Oxygen consump-

Table 1. Summary of the experimental set-up. AFDW: ash-free dry weight

\begin{tabular}{|c|c|c|}
\hline & Capitella sp. & $\begin{array}{c}\text { Ophryotrocha } \\
\text { craigsmithi }\end{array}$ \\
\hline \multicolumn{3}{|l|}{ Experimental conditions } \\
\hline Salinity & 35 & 35 \\
\hline Temperature $\left({ }^{\circ} \mathrm{C}\right)$ & $9-10$ & $9-10$ \\
\hline $\mathrm{pH}$ & 8 & 8 \\
\hline \multicolumn{3}{|l|}{ Metabolic rates } \\
\hline \multicolumn{3}{|l|}{ Population scale } \\
\hline Start weight (mg AFDW) & $1.8 \pm 0.7$ & $1.3 \pm 0.3$ \\
\hline No. of individuals & 13 & 10 \\
\hline Chamber volume (ml) & $17^{\mathrm{a}}$ & 17 \\
\hline Replicates & 8 & 8 \\
\hline \multicolumn{3}{|l|}{ Individual scale } \\
\hline Start weight (mg AFDW) & $2.1 \pm 1.0$ & $1.2 \pm 0.6$ \\
\hline No. of individuals & 1 & 1 \\
\hline Chamber volume (ml) & $2^{\mathrm{a}}$ & 1 \\
\hline Replicates & 18 & $15^{\mathrm{b}}$ \\
\hline \multicolumn{3}{|c|}{ Nutrients incorporated in tissue growth ${ }^{\mathrm{c}}$} \\
\hline Start weight (mg AFDW) & $1.7 \pm 0.1$ & $1.9 \pm 0.1$ \\
\hline No. of individuals & 66 & 50 \\
\hline Chamber volume (ml) & $1000^{\mathrm{a}}$ & 1000 \\
\hline Replicates & 4 & 4 \\
\hline \multicolumn{3}{|c|}{$\begin{array}{l}{ }^{\mathrm{a}} \text { Marbles were added to mimic natural substrates } \\
{ }^{\mathrm{b}} 3 \text { individuals died during the measurements and were } \\
\text { excluded from the experiment } \\
{ }^{\mathrm{c} P u b l i s h e d ~ i n ~ N e d e r l o f ~ e t ~ a l . ~(2019) ~}\end{array}$} \\
\hline
\end{tabular}

tion rates were calculated as the difference in the rate of $\mathrm{pO}_{2}$ change between the experimental chamber and the control chamber, multiplied by the volume of the chambers and the solubility coefficient for oxygen in seawater (adjusted for salinity of 35 and temperature of $9-10^{\circ} \mathrm{C}$; Benson \& Krause 1980, 1984). To convert oxygen consumption rates to carbon loss, a respiratory quotient of 0.9 was used (Cammen 1985).

Following the oxygen consumption incubations, water from each respiration chamber was sampled, including the control chamber (approximately $1 \mathrm{ml}$ for individual measurements and $10 \mathrm{ml}$ for population measurements). These samples were stored at $-20^{\circ} \mathrm{C}$, for the determination of ammonia excretion rates. Ammonia excretion rates were calculated as ammonia concentrations (see Section 2.3) measured in the experimental chambers minus ammonia concentrations measured in the control chamber, multiplied by chamber volume. Finally, dry matter and ash of the polychaetes were determined, and oxygen consumption and ammonia excretion rates were standardized to $1 \mathrm{~g}$ body weight (AFDW) and per hour. Based on the respiration and excretion measurements, O:N ratios were calculated (mol:mol).

\subsubsection{Nutrients incorporated in tissue growth}

Growth and tissue content ( $\mathrm{C}$ and $\mathrm{N}$ ) data reported in Nederlof et al. (2019) for Capitella sp. and O. craigsmithi fed fresh and preserved salmon faeces were used to calculate the amount of nutrients incorporated in tissue growth. Increase in tissue $\mathrm{C}$ and $\mathrm{N}$ were first calculated per individual polychaete by the difference in body content (mg $\mathrm{C}$ or $\mathrm{N}$ ind.- ${ }^{-1}$ ) between the start and end of the experiment. Subsequently these results were standardized for time (per day) and polychaete weight (1 $\mathrm{g}$ AFDW). For the latter, geometric mean body weight (mg AFDW) of the polychaetes during the growth period was calculated using the following formula:

$$
\text { Geometric mean body weight }=\sqrt{ }\left(W_{\mathrm{f}} \times W_{\mathrm{i}}\right)
$$

where $W_{\mathrm{f}}$ is the average individual final weight (mg AFDW) and $W_{\mathrm{i}}$ is the average individual initial weight (mg AFDW).

\subsection{Analytical analyses}

Diet and polychaete samples were freeze-dried. Diet samples were then ground using a bullet mill. 
Diet and polychaetes samples were analysed for dry matter (freeze-dried) and ash $\left(550^{\circ} \mathrm{C}, 6 \mathrm{~h}\right)$. Diet samples were also analysed for $\mathrm{C}$ and $\mathrm{N}$ content. This was done by combusting the samples with an elemental analyser (Flash 2000, Thermo Fisher) at $1020^{\circ} \mathrm{C}$, in the present of oxygen, to convert $\mathrm{C}$ and $\mathrm{N}$ to $\mathrm{CO}_{2}$ and $\mathrm{NO}_{\mathrm{x}}$, respectively. Thereafter, $\mathrm{NO}_{\mathrm{x}}$ was reduced to $\mathrm{N}_{2}$ in a reduction column. Nitrogen content was multiplied by 6.25 to estimate crude protein content in the diets. Sampled material was not enough for fat analyses. Nevertheless, diet samples were collected in parallel with samples collected by Nederlof et al. (2019), and therefore diets are assumed to be comparable between the 2 studies. Nederlof et al. (2019) reported fatty acid contents of the diets.

Water samples taken to determine ammonia excretion rates were thawed to room temperature and analysed using the phenol blue method described by Solórzano (1969). Briefly, $8 \mu \mathrm{l}$ of a phenol alcohol solution (10 g phenol in $100 \mathrm{ml} \mathrm{95 \%}$ ethyl alcohol), $8 \mu \mathrm{l}$ of a $0.5 \%$ sodium nitroferricyanide solution (1 $\mathrm{g}$ sodium nitroferricyanide in $200 \mathrm{ml}$ deionized water) and $20 \mu \mathrm{l}$ oxidizing solution (100 g trisodium citrate and $5 \mathrm{~g}$ sodium hydroxide in $500 \mathrm{ml}$ deionized water; on the day of the analysis, $100 \mathrm{ml}$ of this solution was mixed with $25 \mathrm{ml}$ sodium hypochlorite) were added to $200 \mu \mathrm{l}$ of the water sample in a well plate (volume: $300 \mu \mathrm{l}$ ). This was left for $1 \mathrm{~h}$ at room temperature, after which absorbance was measured using a spectrophotometer $(640 \mathrm{~nm}$, SpectraMax M5 with SoftMax Pro software, Molecular Devices LLC). Standard curves were made using ammonium sulphate $(1.5 \mathrm{mg}$ ammonium sulphate in $1 \mathrm{l}$ deionized water). way ANOVA was used to test differences between diet composition (AFDW, C, N and crude protein). As described by Garland \& Adolph (1994), statistical comparison of species should be done with care. Since the aim of the present study was to estimate the bioremediation potential of each polychaete species independently, 1-way ANOVA was used to test, within each polychaete species, the effect of diet on respiration, excretion and O:N ratios. Where assumptions of homogeneity of variance or normality were violated, data were transformed. If after transformation, assumptions of homogeneity of variance and normality were still violated, a non-parametric Kruskal-Wallis test was used. When the ANOVA tests were significant $(\mathrm{p}<$ 0.05), treatments were compared using Tukey's HSD post hoc multiple comparison tests. Significant results found with the non-parametric test were followed by Mann-Whitney $U$-test with Bonferroni correction.

\section{RESULTS}

\subsection{Diets}

Composition of diets fed to the polychaetes can be found in Table 2. Preservation by acidification affected diet composition, as this resulted in a significantly lower AFDW (Tukey HSD; $\mathrm{p}<0.001$ ), N (MannWhitney $U_{i} \mathrm{p}<0.01$ ) and crude protein (MannWhitney $U_{i} \mathrm{p}<0.01$ ) content compared to the other 2 diets, which did not differ. C content was significantly higher in the dried diet compared to the acidified diet (Tukey HSD; $\mathrm{p}<0.05$ ). Both preserved diets did not significantly differ in $\mathrm{C}$ content compared with the fresh salmon faeces (Tukey HSD; $\mathrm{p}>0.05$ ).

\subsection{Statistical analyses}

Statistical analyses were performed using the $\mathrm{R}$ statistical program (version 3.4.0.; R Development Core Team 2017).

Prior to statistical analysis, residuals of the data were checked for homogeneity of variance and normality using Q-Q plots and Shapiro-Wilk and Levene tests. Student's $t$-test was performed to assess potential differences in respiration and excretion rates between measurements on individual and population scale. One-
Table 2. Composition of experimental diets fed to polychaetes in the weeks prior to respiration and excretion measurements, i.e. fresh salmon faeces and salmon faeces preserved by acidification (formic acid, $\mathrm{pH}<4$ ) or by oven-drying $\left(100^{\circ} \mathrm{C}\right)$. Values are mean $\pm \mathrm{SD}\left(\mathrm{n}=6\right.$ samples treatment $^{-1}$, except for AFDW of the fresh treatment, where $\mathrm{n}=16$ samples). AFDW data were log transformed before statistical analyses; non-parametric test was used for potential differences in $\mathrm{N}$ and crude protein content of the diets. ${ }^{\mathrm{a}, \mathrm{b}}$ Means within a row lacking a common superscript letter differ significantly $(\mathrm{p}<0.05) .{ }^{*} \mathrm{p}<0.05$, ${ }^{* *} \mathrm{p}<0.01,{ }^{* * *} \mathrm{p}<0.001$

\begin{tabular}{|c|c|c|c|c|}
\hline & Fresh & Acid & Dried & Signif. \\
\hline AFDW ( $\mathrm{g} \mathrm{kg}^{-1}$ dry matter) & $790 \pm 37^{\mathrm{a}}$ & $700 \pm 39^{b}$ & $782 \pm 21^{\mathrm{a}}$ & a ${ }^{* * *}$ \\
\hline $\mathrm{C}\left(\mathrm{g} \mathrm{kg}^{-1} \mathrm{AFDW}\right)$ & $437 \pm 12^{\mathrm{a}, \mathrm{b}}$ & $435 \pm 11^{b}$ & $450 \pm 4^{\mathrm{a}}$ & * \\
\hline $\mathrm{N}\left(\mathrm{g} \mathrm{kg}^{-1}\right.$ AFDW $)$ & $24 \pm 3^{\mathrm{a}}$ & $14 \pm 2^{\mathrm{b}}$ & $25 \pm 3^{\mathrm{a}}$ & ** \\
\hline Crude protein $\left(\mathrm{N} \times 6.25 \mathrm{~g} \mathrm{~kg}^{-1} \mathrm{AFDW}\right)$ & $149 \pm 21^{\mathrm{a}}$ & $89 \pm 12^{b}$ & $157 \pm 21^{\mathrm{a}}$ & a $\quad * *$ \\
\hline
\end{tabular}


Table 3. C and N required for metabolic processes based on respiration and excretion and subsequent O:N ratios of Capitella sp. and Ophryotrocha craigsmithi fed 3 different diets (fresh, acid-preserved and oven-dried salmon faeces). Values are mean \pm SD $(n=8$ tanks treatment ${ }^{-1}$ ). All data of Capitella sp. and excretion data and O:N ratios of $O$. craigsmithi were log transformed before statistical analyses. ${ }^{\mathrm{a}, \mathrm{b}}$ Means within a row lacking a common superscript letter differ significantly $(\mathrm{p}<0.05) .{ }^{*} \mathrm{p}<0.05,{ }^{* *} \mathrm{p}<0.01$, ns: not significant

\begin{tabular}{|c|c|c|c|c|c|c|c|c|}
\hline & \multicolumn{4}{|c|}{-Capitella sp. } & \multicolumn{4}{|c|}{ - O. craigsmithi } \\
\hline & Fresh & Acid & Dried & Signif. & Fresh & Acid & Dried & Signif. \\
\hline Respiration (mg C g ${ }^{-1}$ AFDW d ${ }^{-1}$ ) & $2.94 \pm 1.16$ & $2.51 \pm 0.73$ & $4.92 \pm 3.85$ & ns & $7.88 \pm 3.01$ & $6.70 \pm 2.82$ & $9.36 \pm 1.82$ & ns \\
\hline Excretion (mg N g ${ }^{-1}$ AFDW d ${ }^{-1}$ ) & $0.39 \pm 0.22$ & $0.26 \pm 0.10$ & $0.59 \pm 0.42$ & ns & $1.37 \pm 0.42^{\mathrm{b}}$ & $2.15 \pm 0.41^{\mathrm{a}}$ & $2.04 \pm 1.09^{a, b}$ & * \\
\hline $\mathrm{O}: \mathrm{N}$ ratio (mol:mol) & $14 \pm 14$ & $15 \pm 10$ & $12 \pm 4$ & ns & $8 \pm 4^{\mathrm{a}}$ & $4 \pm 2^{\mathrm{b}}$ & $7 \pm 2^{\mathrm{a}}$ & ** \\
\hline
\end{tabular}

\subsection{Polychaete respiration and excretion rates}

Excretion rate of Ophryotrocha craigsmithi was affected by diet, and polychaetes fed the acid-preserved diet had a significantly higher ammonia excretion rate compared to polychaetes fed the fresh diet (Table 3; Tukey HSD; $\mathrm{p}<0.05$ ). Excretion rate of $O$. craigsmithi fed the oven-dried diet did not significantly differ from $O$. craigsmithi fed the 2 other diets (Table 3; Tukey HSD; p > 0.05). A significant diet effect was also found for the $\mathrm{O}: \mathrm{N}$ ratios measured for O. craigsmithi (Table 3; 1-way ANOVA; $\mathrm{p}<0.01$ ); $O$. craigsmithi fed the acid-preserved diet had a significantly lower O:N ratio compared to O. craigsmithi fed the other 2 diets (Table 3; Tukey HSD; $\mathrm{p}<0.05)$. The latter did not significantly differ from each other (Table 3; Tukey HSD; p > 0.05). Respiration rates of $O$. craigsmithi were not affected by diets (Table 3; 1-way ANOVA; $\mathrm{p}>0.05$ ). For
Capitella sp., no diet effect was observed for respiration rates, excretion rates and $\mathrm{O}: \mathrm{N}$ ratio (Table 3; 1-way ANOVA; $\mathrm{p}>0.05$ ).

Both polychaete species did not show significant differences when respiration and excretion rates were measured either at population or individual scale (Fig. 1; Student's $t$-test; $\mathrm{p}>0.05$ ). Overall, for $O$. craigsmithi, higher respiration and excretion rates were observed in comparison to rates measured for Capitella sp., while Capitella sp. showed higher O:N ratios.

\section{3. $\mathrm{C}$ and $\mathrm{N}$ mass balances}

Fig. 2 shows nutrient requirements of Capitella sp. and $O$. craigsmithi, including $\mathrm{C}$ and $\mathrm{N}$ required for, respectively, respiration and excretion combined with nutrients incorporated in body tissue.
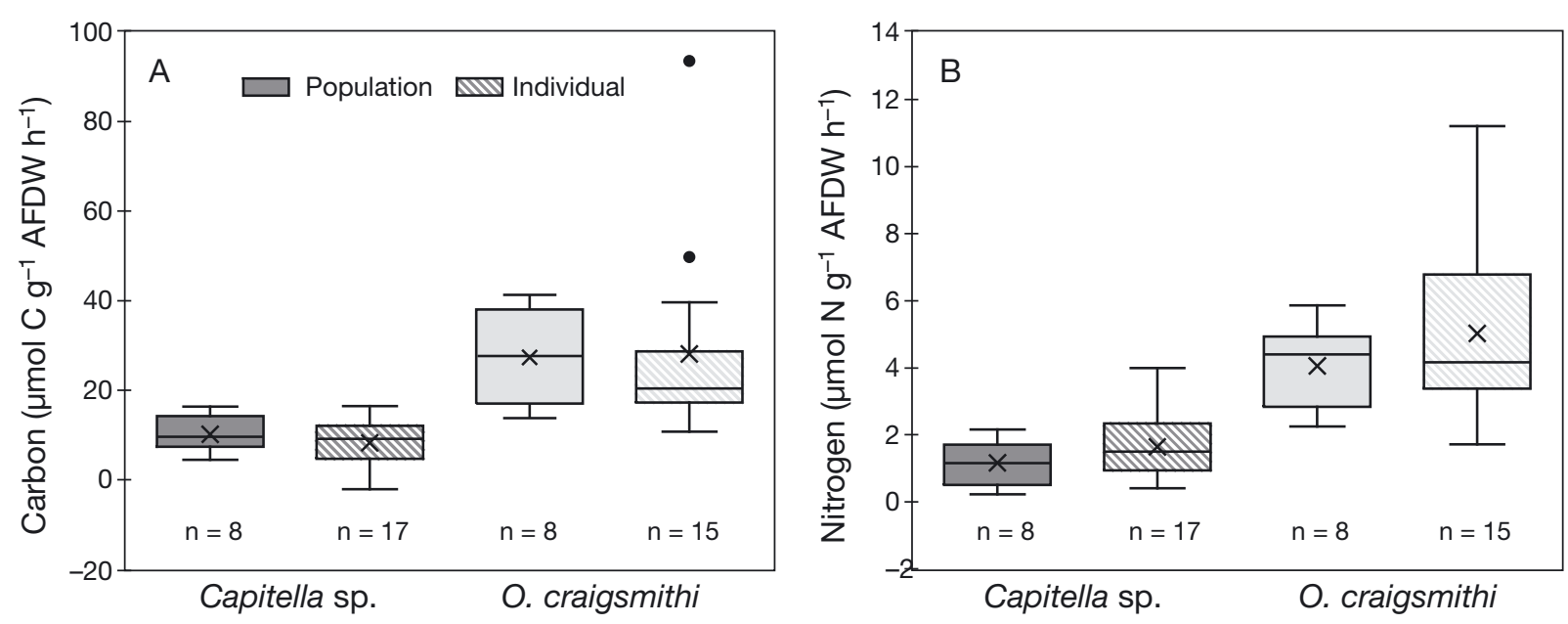

Fig. 1. (A) C and (B) N required for metabolic processes (i.e. respiration and ammonia excretion), measured at population and individual scale for Capitella sp. and Ophryotrocha craigsmithi fed fresh salmon faeces. C requirement based on respiration measurements; nitrogen requirement based on ammonia excretion measurements. Box: interval between lower and upper quartiles of the distributions; cross: mean value; whiskers: minimum and maximum. Data of O. craigsmithi log transformed before statistical analyses. Within each species, no significant differences $(p>0.05)$ were found between measurements at population or individual scale for both $\mathrm{C}$ and $\mathrm{N}$ requirement 


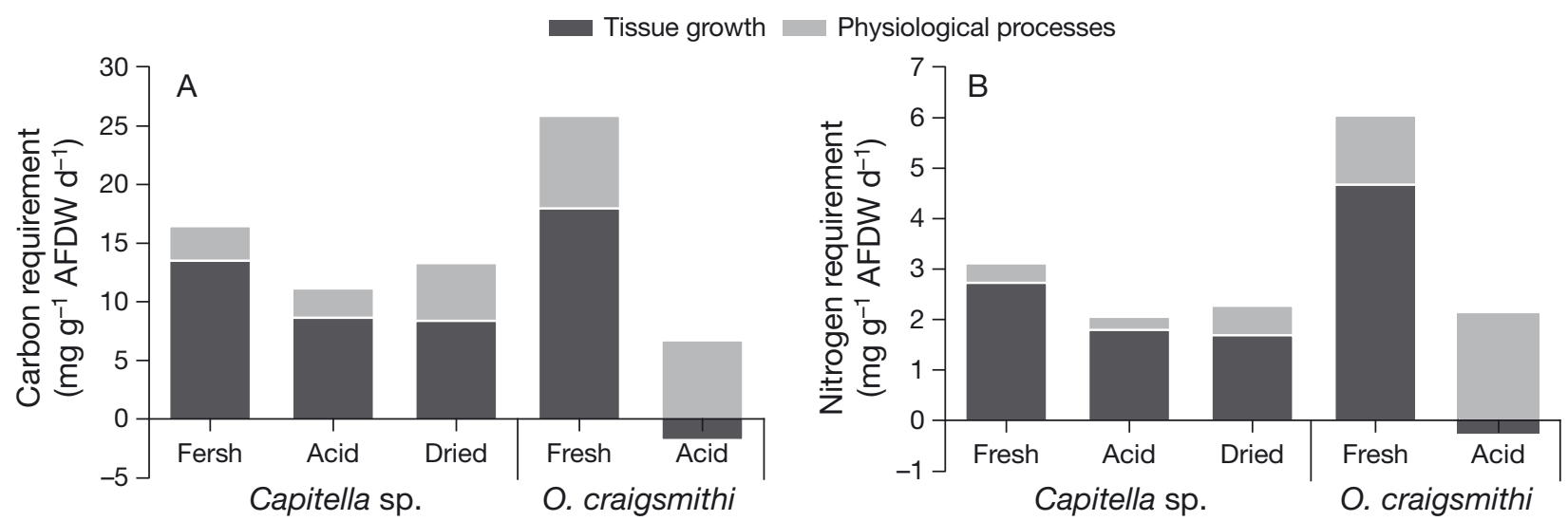

Fig. 2. (A) C and (B) N requirement estimated for Capitella sp. and Ophryotrocha craigsmithi fed fresh or preserved (acidified or oven-dried) salmon faeces. For nutrients incorporated into tissue growth, growth and tissue content data from Nederlof et al. (2019) were used (see also our Section 2.2.3 for calculation methods). Nutrients required for physiological processes were based on respiration $(\mathrm{C})$ and excretion $(\mathrm{N})$ measurements from the present study (see Section 2.2 .2 and Table 3)

For Capitella sp., $\mathrm{C}$ and $\mathrm{N}$, incorporation rates ranged between 8 and $13 \mathrm{mg} \mathrm{C}^{-1}$ AFDW d ${ }^{-1}$ and between 2 and $3 \mathrm{mg} \mathrm{N} \mathrm{g}^{-1}$ AFDW d ${ }^{-1}$, with the highest values found for animals fed the fresh diet. Feeding $O$. craigsmithi the acid-preserved diet resulted in negative values for $\mathrm{C}$ and $\mathrm{N}$ incorporation, due to negative growth rates as reported by Nederlof et al. (2019), while for O. craigsmithi fed fresh salmon faeces, the highest $\mathrm{C}$ and $\mathrm{N}$ incorporation rates were observed (18 and $5 \mathrm{mg} \mathrm{g}^{-1}$ AFDW $\mathrm{d}^{-1}$ for $\mathrm{C}$ and $\mathrm{N}$ respectively).

With the exception of $O$. craigsmithi fed the acid diet, for both polychaete species it was observed that growth makes up a significant fraction in the overall $\mathrm{C}$ and $\mathrm{N}$ requirement (up to $82 \%$ for $\mathrm{C}$ for Capitella sp. on the fresh diet, and up to $87 \%$ for $\mathrm{N}$ for Capitella sp. on the fresh and acid diets). Overall, C requirement ranged between 11 and $16 \mathrm{mg} \mathrm{C} \mathrm{g}^{-1}$ AFDW d ${ }^{-1}$ for Capitella sp. and between 5 and $26 \mathrm{mg}$ $\mathrm{C} \mathrm{g}^{-1}$ AFDW d $\mathrm{d}^{-1}$ for $O$. craigsmithi. $\mathrm{N}$ requirement ranged between 2 and $3 \mathrm{mg} \mathrm{N} \mathrm{g}{ }^{-1}$ AFDW d ${ }^{-1}$ for Capitella sp. and between 2 and $6 \mathrm{mg} \mathrm{N} \mathrm{g}^{-1}$ AFDW $\mathrm{d}^{-1}$ for $O$. craigsmithi.

\section{DISCUSSION}

This study estimated the bioremediation potential of Capitella sp. and Ophryotrocha craigsmithi for a salmon-polychaete integrated system. Metabolic rates and the amount of nutrients incorporated in biomass differed between the diets fed, which has consequences for the bioremediation potential in coupled and decoupled IMTA systems.

\subsection{Polychaete metabolism}

\subsubsection{Metabolic activity of Capitella sp. and $O$. craigsmithi}

A 6 times lower respiration rate was measured in this study for $O$. craigsmithi $\left(26-36 \mu \mathrm{mol} \mathrm{O}_{2} \mathrm{~g}^{-1}\right.$ AFDW $\mathrm{h}^{-1}$ ) compared to rates reported for O. labronica (Rodríguez-Romero et al. 2016). Although factors such as differences in species and experimental setup should not be excluded, the higher respiration rate observed by Rodríguez-Romero et al. (2016) may be attributed to the higher incubation temperature $\left(\mathrm{Q}_{10}\right.$ rule; e.g. Hochachka 1991$)$, i.e. $20^{\circ} \mathrm{C}$ in RodríguezRomero et al. (2016) versus $9-10^{\circ} \mathrm{C}$ in the current study. Both respiration and ammonia excretion rates (4-6 $\mu \mathrm{mol} \mathrm{N} \mathrm{g}{ }^{-1}$ AFDW $\mathrm{h}^{-1}$ ) of $O$. craigsmithi were in line with rates measured during a pilot study for the same species and under comparable environmental conditions $\left(48 \mu \mathrm{mol} \mathrm{O} \mathrm{O}^{-1}\right.$ AFDW h ${ }^{-1}$ and $7 \mu \mathrm{mol} \mathrm{N}$ $\mathrm{g}^{-1} \mathrm{AFDW} \mathrm{h}^{-1}$ ) (Brennan 2018), while a twice as high respiration rate was observed in an earlier pilot study for Ophryotrocha spp. (Eikje 2013).

Even though, based on incubation temperatures, higher rates were expected, both Chareonpanich et al. $(1994)\left(20^{\circ} \mathrm{C}\right)$ and Gillam $(2016)\left(15-20^{\circ} \mathrm{C}\right)$ reported, for Capitella sp. and C. teleta respectively, respiration rates which were in line with the rates measured in our study. Other studies reported higher respiration rates (Brennan 2018, $11^{\circ} \mathrm{C}$; Gamenick et al. 1998, $18^{\circ} \mathrm{C}$; Linke-Gamenick et al. $2000,18^{\circ} \mathrm{C}$ ), but lower ammonia excretion rates (Brennan 2018, $11^{\circ} \mathrm{C}$; Gardner et al. 1993, 20-25 ${ }^{\circ} \mathrm{C}$ ) for Capitella spp. These results may suggest that metabolic rates are highly 
plastic, as was shown for other ectotherms collected from sites different in thermal histories (e.g. latitudes) (Sokolova \& Pörtner 2003, Whiteley et al. 2011). Other factors could also play a role in the differences in metabolic rates reported - size differences for example, since animals in both Brennan (2018) and Gardner et al. (1993) had a higher average individual weight than animals used in our study, suggesting that in those studies, the animals were larger. Furthermore, in the different studies, animals might have differed in their physiological status. Metabolic rates are highly influenced by the physiological status of an individual, and changes in O:N ratios can for example provide information on the reproductive status of an animal (Barber \& Blake 1985). O:N ratios were measured, but not over time, and conclusions on the reproductive status based on a single time moment can be risky (Jansen et al. 2012). Respiration and excretion measurements were done with individuals from the same batch as used in the experiment in Nederlof et al. (2019), where reproduction in the tanks with Capitella sp. was observed, and it is therefore likely that in the current study, metabolic rates of Capitella sp. were influenced by their reproductive status. In both our study species, the O:N ratios fall within the ranges indicative for a protein-driven metabolism (3-16) (Mayzaud 1973), but the lower values indicate that the metabolism of $O$. craigsmithi may rely more on proteins compared to Capitella sp.

While in the holding tanks, individuals of $O$. craigsmithi clustered together in polychaete-mucus complexes, clustering in dense polychaete patches was not observed for Capitella sp. (M. A. J. Nederlof pers. obs.). It was hypothesized that the natural formation of mucus-polychaete complexes observed for $O$. craigsmithi (Salvo et al. 2014) and the formation of dense polychaete patches observed for Capitella sp. (Tsutsumi et al. 2002) would affect metabolic rates. No population-specific effects on respiration and excretion rates were observed for both polychaete species, suggesting that measurements obtained on an individual level can directly be scaled to the population level. It should be noted though that the clustering behaviour of $O$. craigsmithi observed in the holding tanks was not seen in the respiration chambers, and it can therefore not be excluded that population-specific effects do play a role.

\subsubsection{Effect of diet preservation}

Diets used in this study differed in nutrient composition; the oven-dried faeces contained a higher $\mathrm{C}, \mathrm{N}$ and crude protein content (on an AFDW basis) compared to faeces preserved by acidification, but it was not different from the fresh salmon faeces. In Nederlof et al. (2019), similar diets were used, and a significantly higher total fatty acid content was reported for the fresh and acid diet compared to the ovendried diet $\left(100^{\circ} \mathrm{C}\right)$. In aerobic metabolic processes, macronutrients differ in their degree of oxidation, and therefore respiration is influenced by diet composition (Richardson 1929). Lipid metabolism requires relatively lower oxygen consumption (Richardson 1929), and lower respiration rates for polychaetes fed the fresh and acid-preserved diets can thus be expected compared to the oven-dried diet. Although values were indeed lower, no significant diet effect was found.

No difference in excretion rates and O:N ratios were observed for Capitella sp. fed the 3 different diets, while for $O$. craigsmithi, both parameters were affected by diet. The increased ammonia excretion rate of $O$. craigsmithi fed the acid diet compared to the fresh diet, and as a result the reduced O:N ratio, suggests that feeding $O$. craigsmithi with acidpreserved salmon faeces results in a higher protein turnover. This was surprising, since $\mathrm{N}$ and crude protein content of the acid diet was significantly lower compared to the other 2 diets, and it remains unclear why $O$. craigsmithi increased ammonia excretion when fed the acid diet. Interestingly, from a bioremediation perspective, the respiration results do suggest that for decoupled systems, preservation of waste by oven-drying would result in a higher $\mathrm{C}$ removal, while the excretion results indicate that for $\mathrm{N}$ removal, preservation by acidification is preferred.

\subsection{Bioremediation potential}

\subsection{1. $\mathrm{C}$ and $\mathrm{N}$ mass balance}

Bioremediation potential can be defined as the relationship between nutrient intake, growth (and reproduction), respiration/excretion and egestion. Several approaches are used to determine this potential, each with their own advantages and disadvantages (Table 4). Which approach is selected is often driven by practical or methodological constraints. In the present study, the initial aim was to define all processes described as approaches II-IV in Table 4. Pilot tests showed, however, that quantification of food intake and assimilation were not accurate due to mucus excreted by the polychaetes - feed and faeces were trapped in this mucus layer, from where it no longer 
Table 4. Overview of approaches applied in integrated multi-trophic aquaculture (IMTA) studies to define bioremediation potential of extractive species

\begin{tabular}{|c|c|c|c|c|}
\hline & Approach & Advantage & Disadvantage & References \\
\hline I & $\begin{array}{l}\text { Bioremediation is } \\
\text { defined as the amount } \\
\text { of nutrients incorpo- } \\
\text { rated in cultivated or } \\
\text { harvested biomass, } \\
\text { determined by growth } \\
\text { and nutrient content of } \\
\text { the extractive species }\end{array}$ & $\begin{array}{l}\text { (1) When extractive species are } \\
\text { harvested, this presents the } \\
\text { actual amount of nutrients } \\
\text { removed from the system } \\
\text { (2) Relatively easy method that } \\
\text { can be applied in both field } \\
\text { and laboratory studies } \\
\text { (3) No need to determine the } \\
\text { origin (i.e. waste or ambient) } \\
\text { of nutrients taken up by the } \\
\text { extractive species }\end{array}$ & $\begin{array}{l}\text { (1) Overestimates organic ex- } \\
\text { tractive species' maximum } \\
\text { cultivation biomass, since } \\
\text { waste consumption is not taken } \\
\text { into account } \\
\text { (2) Underestimates benthic } \\
\text { bioremediation potential, since } \\
\text { respiration/excretion and } \\
\text { bioturbation processes are not } \\
\text { taken into account }\end{array}$ & $\begin{array}{l}\text { e.g. Krom et al. } \\
\text { (1995), } \\
\text { Sanderson et al. } \\
\text { (2012), } \\
\text { Wang et al. } \\
\text { (2012) }\end{array}$ \\
\hline II & $\begin{array}{l}\text { Bioremediation is } \\
\text { defined as the amount } \\
\text { of nutrients removed } \\
\text { due to consumption, } \\
\text { determined by food } \\
\text { intake rates of the } \\
\text { extractive species }\end{array}$ & $\begin{array}{l}\text { (1) Relatively easy method when } \\
\text { applied in laboratory studies, } \\
\text { with non-mucus-producing } \\
\text { extractive species } \\
\text { (2) A good method to determine } \\
\text { maximum cultivation biomass } \\
\text { for organic extractive species }\end{array}$ & $\begin{array}{l}\text { (1) Overestimates bioremediation } \\
\text { potential, since egestion is not } \\
\text { taken into account } \\
\text { (2) A less suitable method for } \\
\text { mucus-producing extractive } \\
\text { species, when feed, mucus and } \\
\text { faeces are hard to separate }\end{array}$ & $\begin{array}{l}\text { e.g. Honda \& } \\
\text { Kikuchi (2002), } \\
\text { Brown et al. } \\
(2011)\end{array}$ \\
\hline III & $\begin{array}{l}\text { Bioremediation is } \\
\text { defined as the differ- } \\
\text { ence between food } \\
\text { intake and egestion, } \\
\text { i.e. assimilation, } \\
\text { determined by the } \\
\text { Conover method, } \\
\text { among others }\end{array}$ & $\begin{array}{l}\text { (1) No need for quantitative } \\
\text { recovery of extractive } \\
\text { species' faeces, and therefore } \\
\text { a relatively easy method for } \\
\text { non-mucus-producing } \\
\text { extractive species } \\
\text { (2) Can be applied in both field } \\
\text { and laboratory studies }\end{array}$ & $\begin{array}{l}\text { (1) Does not take into account the } \\
\text { amount of waste ingested by } \\
\text { the extractive species. If food } \\
\text { consumption is unknown, this } \\
\text { method can only provide } \\
\text { qualitative bioremediation, and } \\
\text { not quantitative bioremediation } \\
\text { (2) A less suitable method for } \\
\text { mucus-producing extractive } \\
\text { species, when feed, mucus and } \\
\text { faeces are hard to separate }\end{array}$ & $\begin{array}{l}\text { e.g. Paltzat et } \\
\text { al. (2008), } \\
\text { Fang et al. } \\
(2016 a)\end{array}$ \\
\hline IV & $\begin{array}{l}\text { Bioremediation is } \\
\text { defined by respiration/ } \\
\text { excretion as a proxy } \\
\text { for maintenance of } \\
\text { physiological processes }\end{array}$ & $\begin{array}{l}\text { (1) Can be applied to small } \\
\text { individuals and mucus-pro- } \\
\text { ducing extractive species } \\
\text { (2) Can be applied in both field } \\
\text { and laboratory studies }\end{array}$ & $\begin{array}{l}\text { (1) Underestimates bioremediation } \\
\text { potential, since consumption } \\
\text { and assimilation are not taken } \\
\text { into account } \\
\text { (2) Can only be applied when } \\
\text { benthic bioremediation is } \\
\text { studied }\end{array}$ & $\begin{array}{l}\text { e.g. Honda \& } \\
\text { Kikuchi (2002) }\end{array}$ \\
\hline $\mathrm{V}$ & $\begin{array}{l}\text { Bioremediation is } \\
\text { defined by all pro- } \\
\text { cesses described in } \\
\text { approaches II-IV, } \\
\text { determined by scope } \\
\text { for growth }\end{array}$ & $\begin{array}{l}\text { (1) Provides the most insights } \\
\text { into the bioremediation } \\
\text { capacity of extractive species }\end{array}$ & $\begin{array}{l}\text { (1) Labour intensive } \\
\text { (2) A less suitable method for } \\
\text { mucus-producing extractive } \\
\text { species, when feed, mucus and } \\
\text { faeces are hard to separate } \\
\text { (3) Less suitable for field studies }\end{array}$ & $\begin{array}{l}\text { e.g. Jansen et } \\
\text { al. (2012), } \\
\text { Irisarri et al. } \\
\text { (2015), Fang et } \\
\text { al. (2016b) }\end{array}$ \\
\hline
\end{tabular}

could be removed. In particular, it was observed (visually) that $O$. craigsmithi 'actively' stored food and faeces in mucus strings. Besides splitting food and faeces, mucus also interfered with OM collection, since filters were easily clogged. Furthermore, the small size of the animals resulted in small faeces fragments, making it difficult to separate polychaete faeces from food leftovers, as is done for larger polychaetes to define assimilation (e.g. Fang et al. 2016a). Instead, bioremediation potential was estimated based on nutrient requirements for growth and metabolic processes. This method excludes information on consumption and $\mathrm{AE}$, overestimating waste turnover capacity. Nevertheless, relatively high $\mathrm{AE}$ values have been reported for polychaetes fed aquaculture waste $(65-80 \%$ for both N and C) (Honda \& Kikuchi 2002, Fang et al. 2016a,b). Hence it is assumed that polychaetes are efficient convertors of fish faeces, and that nutrient requirements for growth and metabolic processes provide a good estimate of their bioremediation potential.

Nutrient requirements determined in this study resulted in rates of $16 \mathrm{mg} \mathrm{C} \mathrm{g}^{-1} \mathrm{AFDW} \mathrm{d}{ }^{-1}$ and $3 \mathrm{mg}$ 
$\mathrm{N} \mathrm{g}^{-1}$ AFDW d ${ }^{-1}$ for Capitella sp. and $26 \mathrm{mg} \mathrm{C} \mathrm{g}^{-1}$ AFDW d ${ }^{-1}$ and $6 \mathrm{mg} \mathrm{N} \mathrm{g}^{-1}$ AFDW d ${ }^{-1}$ for $O$. craigsmithi fed fresh faeces. To compare with the literature, these rates were converted to $g$ wet weight (WW), resulting in $3.5 \mathrm{mg} \mathrm{C} \mathrm{g}^{-1} \mathrm{WW} \mathrm{d}^{-1}$ and $0.7 \mathrm{mg} \mathrm{N} \mathrm{g}^{-1} \mathrm{WW} \mathrm{d}^{-1}$ for Capitella sp. and $4 \mathrm{mg} \mathrm{C} \mathrm{g}^{-1} \mathrm{WW} \mathrm{d}^{-1}$ and $1 \mathrm{mg} \mathrm{N} \mathrm{g}^{-1}$ WW d ${ }^{-1}$ for O. craigsmithi. Fang et al. (2016b) reported a $\mathrm{C}$ and $\mathrm{N}$ budget for Perinereis aibuhitensis fed defrosted fish faeces. Combining their data on growth and metabolism resulted in requirements of $2 \mathrm{mg} \mathrm{C} \mathrm{g}^{-1}$ WW d ${ }^{-1}$ and $0.24 \mathrm{mg} \mathrm{N} \mathrm{g}^{-1} \mathrm{WW} \mathrm{d}{ }^{-1}$, which is lower than the values obtained in the present study. Honda \& Kikuchi (2002) reported a N budget for P. nuntia vallata fed flounder faeces, and combining their data on growth and metabolism resulted in a requirement of $0.82 \mathrm{mg} \mathrm{N} \mathrm{g}^{-1} \mathrm{WW} \mathrm{d}^{-1}$, which is in line with our study. Interestingly, the $\mathrm{C}$ budget for $P$. aibuhitensis presented by Fang et al. (2016b) was dominated by nutrients required for metabolic processes $(56-82 \%$ of consumed carbon), while in the current study, $\mathrm{C}$ incorporated in tissue growth dominated the mass balance. In the $\mathrm{N}$ budget of $P$. aibuhitensis, relatively more $\mathrm{N}$ was allocated for growth $(60-64 \%$ of consumed $\mathrm{N}$ ), compared to excretory $\mathrm{N}$ (8-15\% of consumed N) (Fang et al. 2016b), which was similar to the current study. Still, especially for O. craigsmithi fed fresh faeces, it was observed that nutrients required for metabolic processes made up a notable fraction of the total requirement (20-30\%), highlighting the importance of metabolic processes in organic waste reduction by extractive species. Overall, compared to other studies, both Capitella sp. and $O$. craigsmithi show a high potential for waste bioremediation.

\subsubsection{Farm-scale bioremediation}

Organic waste production measured during peak moments of salmon cultivation in a commercial farm in Norway can reach up to $2500 \mathrm{mg}$ organic $\mathrm{C} \mathrm{m}^{-2} \mathrm{~d}^{-1}$ (Kutti et al. 2007a), which can negatively impact benthic ecosystems (Kutti et al. 2007a,b, 2008). Based on $C$ requirements determined in the present study, it can be estimated that for $100 \%$ removal of the daily organic $\mathrm{C}$ waste flux, approximately 65000 ind. $\mathrm{m}^{-2}$ (152 $\mathrm{g} \mathrm{AFDW} \mathrm{m}^{-2}$ ) of Capitella sp. or 37000 ind. $\mathrm{m}^{-2}$ (97 $\mathrm{g}$ AFDW m ${ }^{-2}$ ) of $O$. craigsmithi are required in coupled systems where the polychaetes are provided with fresh faeces (Table 5). These numbers need to increase in decoupled systems, where fish waste is preserved before being fed to the polychaetes (Table 5). It should be noted that the numbers provided in Table 5 are an overestimation, since consumption was not measured. Nevertheless, as mentioned earlier (Section 4.2.1), polychaetes are assumed to be efficient waste convertors (Fang et al. 2016b).

Underneath fish farms, opportunistic polychaete species such as Capitella spp. and Ophryotrocha spp. can reach high densities (Tsutsumi et al. 2005, Kutti et al. 2007b, Salvo et al. 2015b, Jansen et al. 2019). Tsutsumi et al. (2005) cultivated Capitella sp. underneath a fish farm (Pagrus major and Seriola quinqueradiata) in the Kuusura Bay in Japan and reported population densities of approximately 130000 ind. $\mathrm{m}^{-2}$. Paxton \& Davey (2010) estimated that the density of $O$. shieldsi underneath sea cages (Salmo salar) at Macquarie Harbour in Tasmania, Australia, reached up to 100000 ind. $\mathrm{m}^{-2}$. Quantitative data on polychaete abundances underneath salmon farms in Norway is limited, as the depth of fjord systems makes it a challenge to measure these abundances (Jansen et al. 2019). However, in the current study, the estimated densities required for $100 \%$ waste removal (Table 5) fall within the ranges reported in the literature.

It should be noted that $100 \%$ waste removal does not equal $100 \%$ waste reduction to the benthic environment, as polychaetes expel faeces as well. Hughes (2016) indicated that there is a need to define IMTA

Table 5. Capitella sp. and Ophryotrocha craigsmithi biomass and number of individuals required to remove 100 or $20 \%$ of the particulate organic carbon (POC) flux to the benthic system of a commercial salmon farm in Norway. Polychaete requirement calculated for coupled (i.e. fresh salmon waste) and decoupled systems where waste preservation is recommended (acid preservation and oven-drying). Deposition rate derived from Kutti et al. (2007a). Carbon requirements are the sum of respiration rates (this study) and tissue growth rates (based on Nederlof et al. 2019). To calculate the number of individuals required, individual geometric mean body weight of $2.35 \mathrm{mg}$ AFDW for Capitella sp. and $2.64 \mathrm{mg}$ AFDW for $O$. craigsmithi was used (based on the growth experiment in Nederlof et al. 2019)

\begin{tabular}{|c|c|c|c|c|c|}
\hline & \multicolumn{3}{|c|}{ Capitella sp. } & \multicolumn{2}{|c|}{ O. craigsmithi } \\
\hline & Fresh & Acid & Dried & Fresh & Acid \\
\hline Deposition rate $\left(\mathrm{mg}\right.$ POC $\left.\mathrm{m}^{-2} \mathrm{~d}^{-1}\right)$ & 2500 & 2500 & 2500 & 2500 & 2500 \\
\hline $\begin{array}{l}\text { Carbon requirement }\left(\mathrm{mg} \mathrm{C} \mathrm{g}^{-1}\right. \\
\text { AFDW d }\end{array}$ & 16 & 11 & 13 & 26 & 5 \\
\hline \multicolumn{6}{|l|}{$100 \%$ POC removal } \\
\hline Biomass required (g AFDW $\mathrm{m}^{-2}$ ) & 152 & 224 & 188 & 97 & 511 \\
\hline Individuals required (ind. $\mathrm{m}^{-2}$ ) & 64643 & 95353 & 79935 & 36664 & 193632 \\
\hline \multicolumn{6}{|l|}{$20 \%$ POC removal } \\
\hline Biomass required (g AFDW m ${ }^{-2}$ ) & 30 & 45 & 38 & 19 & 102 \\
\hline Individuals required (ind. $\mathrm{m}^{-2}$ ) & 12929 & 19071 & 15987 & 7333 & 38726 \\
\hline
\end{tabular}


in terms of environmental performance, raising the question of what percentage of waste should be removed for an effective and sustainable system. In benthic IMTA, the role of microbes in waste mineralization should not be underestimated (Heilskov et al. 2006, Valdemarsen et al. 2012). These microbes can in turn serve as a food source for the polychaetes. The lower bioremediation potential observed for both polychaete species fed the preserved salmon faeces suggests the importance of microbes in their diets, in particular for $O$. craigsmithi. Underneath fish farms, Ophryotrocha species commonly form a complex matrix of polychaetes, mucus and chemoautotrophic bacteria (Salvo et al. 2015b), but the role of these matrixes in the bioremediation of fish waste is not yet understood. Next steps in understanding the full bioremediation capacity of benthic IMTA with Capitella sp. or O. craigsmithi should focus on the interactions that could be encountered at the farm level, like bacteria-polychaete interactions and the aggregation in mucus complexes. It should also be taken into account that opportunistic polychaete species are often characterized by a boom-bust population dynamics, whereby relatively small changes in organic loadings can have large impacts on the population (Ramskov \& Forbes 2008). Polychaete cultivation densities aiming for $100 \%$ waste removal might therefore be risky. Based on the role of microbes and the risk of population collapses, polychaete cultivation densities required for $20 \%$ waste removal are therefore assumed to be more realistic and are also included in Table 5.

While in Nederlof et al. 2019, production potential (i.e. growth and survival) and body composition (i.e. fatty acid and amino acid profiles) of Capitella sp. and $O$. craigsmithi fed salmon faeces were evaluated, the present study shows their bioremediation potential for salmon-polychaete integrated systems. Combined, these studies highlight that both Capitella sp. and $O$. craigsmithi are interesting species to include in IMTA systems. The next steps should focus on cultivation and harvesting techniques, adjusted to the polychaete species selected. For decoupled integrated systems, this would mean that polychaete cultivation units should be developed, but other waste preservation methods should also be explored, as the bioremediation potential was reduced when polychaetes were fed either acidified or dried salmon faeces. Also for coupled integrated systems, the development of polychaete cultivation methods is still in its infancy, but some steps have been taken. Kinoshita et al. (2008) described, for example, a method whereby individuals of Capitella sp. cultivated in a hatchery were introduced under a fish farm. Instead of introducing the polychaetes in coupled integrated systems, there are also opportunities to enhance native polychaete species, as shown by Jansen et al. (2019) for Ophryotrocha spp. and other species. This method can be compared with suspended mussel cultivation (Smaal 2002), in which an artificial substrate is provided (ropes in case of mussels, benthic trays in case of polychaetes) on which juveniles can settle and grow and which are eventually harvested. The fast colonization of benthic production systems shown by Jansen et al. (2019) in combination with the high bioremediation potential estimated in this study highlights the opportunity to boost native Ophryotrocha species as an extractive component in open water IMTA systems.

\subsection{Conclusion}

This study demonstrates that $\mathrm{C}$ requirements range between 11 and $16 \mathrm{mg} \mathrm{C}^{\mathrm{g}} \mathrm{AFDW}^{-1} \mathrm{~d}^{-1}$ and between 5 and $26 \mathrm{mg} \mathrm{C} \mathrm{g} \mathrm{AFDW}^{-1} \mathrm{~d}^{-1}$ for Capitella sp. and $O$. craigsmithi respectively. $\mathrm{N}$ requirements range between 2 and $3 \mathrm{mg} \mathrm{N} g$ AFDW $^{-1} \mathrm{~d}^{-1}$ and between 2 and $6 \mathrm{mg} \mathrm{N} \mathrm{g} \mathrm{AFDW}^{-1} \mathrm{~d}^{-1}$ for Capitella sp. and $O$. craigsmithi respectively. These values were in line with or higher than values reported for other polychaete species, highlighting the potential for fish-waste bioremediation by both Capitella sp. and $O$. craigsmithi. The highest values were observed for $O$. craigsmithi fed fresh salmon faeces. Preservation of salmon waste (either by oven-drying or acidification) reduced the bioremediation potential of both species, which could primarily be ascribed to reduced growth. This suggests the importance of polychaetemicrobe interactions, and shows that in decoupled integrated systems, higher biomass is required to mitigate fish waste, compared to systems where the polychaetes can be cultivated directly underneath the cages (i.e. coupled IMTA). The polychaete densities required for bioremediation of fish waste lay within the ranges reported for wild populations, and development of benthic cultivation systems boosting these numbers of polychaetes above the natural numbers seems therefore a feasible option.

Acknowledgements. We thank Lerøy Vest AS and Marine Harvest AS for access to the farms and help with collection of the polychaetes. We also thank the technical staff of Austevoll Research Station for help with the experimental set-up and laboratory assistance. We thank the editor and 3 anonymous reviewers for their comments and suggested changes to earlier versions of this paper. This research was 
supported by Ocean Forest AS (Research and Development licence FD0036-1608763/Institute of Marine Research), the Norwegian species initiative and carried out as part of the PhD study of M.A.J.N. (IPOP project TripleP@Sea KB-24001-019 at Wageningen University).

\section{LITERATURE CITED}

Bannister RJ, Valdemarsen T, Hansen PK, Holmer M, Ervik A (2014) Changes in benthic sediment conditions under an Atlantic salmon farm at a deep, well-flushed coastal site. Aquacult Environ Interact 5:29-47

* Barber BJ, Blake NJ (1985) Substrate catabolism related to reproduction in the bay scallop Argopecten irradians concentricus, as determined by $\mathrm{O} / \mathrm{N}$ and $\mathrm{RQ}$ physiological indexes. Mar Biol 87:13-18

Benson BB, Krause D Jr (1980) The concentration and isotopic fractionation of gases dissolved in freshwater in equilibrium with the atmosphere. 1. Oxygen. Limnol Oceanogr 25:662-671

* Benson BB, Krause D Jr (1984) The concentration and isotopic fractionation of oxygen dissolved in freshwater and seawater in equilibrium with the atmosphere. Limnol Oceanogr 29:620-632

Bergström P, Carlsson MS, Lindegarth M, Petersen JK, Lindegarth S, Holmer M (2015) Testing the potential for improving quality of sediments impacted by mussel farms using bioturbating polychaete worms. Aquacult Res 48:161-176

Beristain BT (2005) Organic matter decomposition in simulated aquaculture ponds. PhD dissertation, Wageningen University

Betoret E, Calabuig-Jiménez L, Barrera C, Dalla Rosa M (2016) Sustainable drying technologies for the development of functional foods and preservation of bioactive compounds. In: del Real Olvera J (ed) Sustainable drying technologies. IntechOpen, London, p 37-57

Bischoff AA, Fink P, Waller U (2009) The fatty acid composition of Nereis diversicolor cultured in an integrated recirculated system: possible implications for aquaculture. Aquaculture 296:271-276

Brennan N (2018) Studying the waste recycling potential of naturally occurring opportunistic polychaetes on benthic trays under a Norwegian fish farm. MSc thesis, University of Bergen

* Brown N, Eddy S, Plaud S (2011) Utilization of waste from a marine recirculating fish culture system as a feed source for the polychaete worm, Nereis virens. Aquaculture 322-323:177-183

Cammen LM (1985) Metabolic loss of organic carbon by the polychaete Capitella capitata (Fabricius) estimated from initial weight decrease during starvation, oxygen uptake, and release of ${ }^{14} \mathrm{C}$ by uniformly-labeled animals. Mar Ecol Prog Ser 21:163-167

* Chareonpanich C, Montani S, Tsutsumi H, Nakamura H (1994) Estimation of oxygen consumption of a depositfeeding polychaete Capitella sp. I. Fish Sci 60:249-251

Chopin T (2013) Integrated multi-trophic aquaculture: ancient, adaptable concept focuses on ecological integration. Glob Aquacult Advocate 16:16-19

Chopin T (2015) Marine aquaculture in Canada: well-established monocultures of finfish and shellfish and an emerging integrated multi-trophic aquaculture (IMTA) approach including seaweeds, other invertebrates, and microbial communities. Fisheries (Bethesda, Md) 40: 28-31

Eikje EM (2013) Benthic impacts of fish-farm waste on hard bottom habitats, the ecology of opportunistic epifauna polychaetes. MSc thesis, University of Bergen

Fang J, Jiang Z, Jansen HM, Hu F and others (2016a) Applicability of Perinereis aibuhitensis Grube for fish waste removal from fish cages in Sanggou Bay, PR China. J Ocean Univ China 16:294-304

F Fang J, Zhang J, Jiang Z, Du M and others (2016b) Environmental remediation potential of Perinereis aibuhitensis (Polychaeta) based on the effects of temperature and feed types on its carbon and nitrogen budgets. Mar Biol Res 12:583-594

Fauchald K, Jumars PA (1979) The diet of worms: a study of polychaete feeding guilds. Oceanogr Mar Biol Annu Rev 17:193-284

Filgueira R, Guyondet T, Reid G, Grant J, Cranford P (2017) Vertical particle fluxes dominate integrated multi-trophic aquaculture (IMTA) sites: implications for shellfish-finfish synergy. Aquacult Environ Interact 9:127-143

Findlay S, Tenore K (1982) Nitrogen source for a detritivore: detritus substrate versus associated microbes. Science 218:371-373

* Gamenick I, Vismann B, Grieshaber M, Giere O (1998) Ecophysiological differentiation of Capitella capitata (Polychaeta). Sibling species from different sulfidic habitats. Mar Ecol Prog Ser 175:155-166

* Gardner WS, Briones EE, Kaegi EC, Rowe GT (1993) Ammonium excretion by benthic invertebrates and sedimentwater nitrogen flux in the Gulf of Mexico near the Mississippi River outflow. Estuaries 16:799-808

Garland T Jr, Adolph SC (1994) Why not to do two-species comparative studies: limitations on inferring adaptation. Physiol Zool 67:797-828

Gillam KB (2016) Examining the combined effects of dissolved oxygen, temperature, and body size on the physiological responses of a model macrobenthic polychaete species, Capitella teleta. PhD dissertation, University of Southern Mississippi, Hattiesburg, MS

Goddek S, Espinal CA, Delaide B, Jijkli MH, Schmautz Z, Wuertz S, Keesman KJ (2016) Navigating towards decoupled aquaponic systems: a system dynamics design approach. Water 8:303

* Gómez S, Hurtado CF, Orellana J (2019) Bioremediation of organic sludge from a marine recirculating aquaculture system using the polychaete Abarenicola pusilla (Quatrefages, 1866). Aquaculture 507:377-384

Granada L, Sousa N, Lopes S, Lemos MF (2016) Is integrated multitrophic aquaculture the solution to the sectors' major challenges?-a review. Rev Aquacult 8:283-300

Hardy RW, Shearer KD, Spinelli J (1984) The nutritional properties of co-dried fish silage in rainbow trout (Salmo gairdneri) dry diets. Aquaculture 38:35-44

*Hassall M (1983) Population metabolism of the terrestrial isopod Philoscia muscorum in a dune grassland ecosystem. Oikos 41:17-26

* Hebert PD, Cywinska A, Ball SL, Dewaard JR (2003) Biological identifications through DNA barcodes. Proc R Soc B 270:313-321

* Heilskov AC, Alperin M, Holmer M (2006) Benthic fauna bio-irrigation effects on nutrient regeneration in fish farm sediments. J Exp Mar Biol Ecol 339:204-225

Hochachka P (1991) Temperature: the ectothermy option. In: Hochachka PW, Ommsen TP (eds) Biochemistry and 
molecular biology of fishes, Vol 1. Elsevier, Amsterdam, p 313-322

Honda H, Kikuchi K (2002) Nitrogen budget of polychaete Perinereis nuntia vallata fed on the feces of Japanese flounder. Fish Sci 68:1304-1308

Hughes AD (2016) Integrated multi-trophic aquaculture in Europe: Will it work for us? Aquacult Eur 41:5-11

Hughes AD, Black KD (2016) Going beyond the search for solutions: understanding trade-offs in European integrated multi-trophic aquaculture development. Aquacult Environ Interact 8:191-199

Irisarri J, Fernández-Reiriz MJ, Labarta U, Cranford PJ, Robinson SMC (2015) Availability and utilization of waste fish feed by mussels Mytilus edulis in a commercial integrated multi-trophic aquaculture (IMTA) system: a multi-indicator assessment approach. Ecol Indic 48: 673-686

Jansen HM, Strand Ø, Verdegem M, Smaal A (2012) Accumulation, release and turnover of nutrients (C-N-P-Si) by the blue mussel Mytilus edulis under oligotrophic conditions. J Exp Mar Biol Ecol 416-417:185-195

Jansen HM, Hansen PK, Brennan N, Fang J, Stohmeier T, Dahlgren TG, Strand O (2019) Enhancing opportunistic polychaete communities under fish farms: an alternative concept for integrated aquaculture. Aquacult Environ Interact 11:331-336

Kinoshita K, Tamaki S, Yoshioka M, Srithonguthai S and others (2008) Bioremediation of organically enriched sediment deposited below fish farms with artificially mass-cultured colonies of a deposit-feeding polychaete Capitella sp. I. Fish Sci 74:77-87

Krom M, Ellner S, Van Rijn J, Neori A (1995) Nitrogen and phosphorus cycling and transformations in a prototype 'non-polluting' integrated mariculture system, Eilat, Israel. Mar Ecol Prog Ser 118:25-36

Kutti T, Ervik A, Hansen PK (2007a) Effects of organic effluents from a salmon farm on a fjord system. I. Vertical export and dispersal processes. Aquaculture 262: 367-381

Kutti T, Hansen PK, Ervik A, Høisæter T, Johannessen P (2007b) Effects of organic effluents from a salmon farm on a fjord system. II. Temporal and spatial patterns in infauna community composition. Aquaculture 262: 355-366

Kutti T, Ervik A, Høisæeter T (2008) Effects of organic effluents from a salmon farm on a fjord system. III. Linking deposition rates of organic matter and benthic productivity. Aquaculture 282:47-53

Lekang OI, Salas-Bringas C, Bostock JC (2016) Challenges and emerging technical solutions in on-growing salmon farming. Aquacult Int 24:757-766

Linke-Gamenick I, Vismann B, Forbes VE (2000) Effects of fluoranthene and ambient oxygen levels on survival and metabolism in three sibling species of Capitella (Polychaeta). Mar Ecol Prog Ser 194:169-177

Luckstadt C (2008) The use of acidifiers in fish nutrition. Perspect Agric Vet Sci Nutr Nat Resour 3:1-8

Marques B, Calado R, Lillebø AI (2017) New species for the biomitigation of a super-intensive marine fish farm effluent: combined use of polychaete-assisted sand filters and halophyte aquaponics. Sci Total Environ 599-600: 1922-1928

Mayzaud P (1973) Respiration and nitrogen excretion of zooplankton. II. Studies of the metabolic characteristics of starved animals. Mar Biol 21:19-28
Nederlof MAJ, Jansen HM, Dahlgren TG, Fang J and others (2019) Application of polychaetes in (de)coupled integrated aquaculture: production of a high-quality marine resource. Aquacult Environ Interact 11:221-237

* Özyurt G, Gökdoğan S, Şimşek A, Yuvka I, Ergüven M, Kuley Boga E (2016) Fatty acid composition and biogenic amines in acidified and fermented fish silage: a comparison study. Arch Anim Nutr 70:72-86

Pajand ZO, Soltani M, Bahmani M, Kamali A (2017) The role of polychaete Nereis diversicolor in bioremediation of wastewater and its growth performance and fatty acid composition in an integrated culture system with Huso huso (Linnaeus, 1758). Aquacult Res 48:5271-5279

Palmer PJ (2010) Polychaete-assisted sand filters. Aquaculture 306:369-377

* Paltzat DL, Pearce CM, Barnes PA, McKinley RS (2008) Growth and production of California sea cucumbers (Parastichopus californicus Stimpson) co-cultured with suspended Pacific oysters (Crassostrea gigas Thunberg). Aquaculture 275:124-137

\% Paxton H, Davey A (2010) A new species of Ophryotrocha (Annelida: Dorvilleidae) associated with fish farming at Macquarie Harbour, Tasmania, Australia. Zootaxa 2509: 53-61

* Quiñones RA, Fuentes M, Montes RM, Soto D, León-Muñoz $\mathrm{J}$ (2019) Environmental issues in Chilean salmon farming: a review. Rev Aquacult 11:375-402

R Development Core Team (2017) R: a language and environment for statistical computing. R Foundation for Statistical Computing, Vienna

Ramskov T, Forbes VE (2008) Life history and population dynamics of the opportunistic polychaete Capitella sp. I in relation to sediment organic matter. Mar Ecol Prog Ser 369:181-192

* Rastrick S, Whiteley N (2011) Congeneric amphipods show differing abilities to maintain metabolic rates with latitude. Physiol Biochem Zool 84:154-165

* Richardson HB (1929) The respiratory quotient. Physiol Rev 9:61-125

* Rodríguez-Romero A, Jarrold MD, Massamba-N'Siala G, Spicer JI, Calosi P (2016) Multi-generational responses of a marine polychaete to a rapid change in seawater $\mathrm{pCO}_{2}$. Evol Appl 9:1082-1095

Salvo F, Wiklund H, Dufour SC, Hamoutene D, Pohle G, Worsaae K (2014) A new annelid species from whalebones in Greenland and aquaculture sites in Newfoundland: Ophryotrocha cyclops, sp. nov. (Eunicida: Dorvilleidae). Zootaxa 3887:555-568

Salvo F, Dufour SC, Hamoutene D, Parrish CC (2015a) Lipid classes and fatty acids in Ophryotrocha cyclops, a dorvilleid from Newfoundland aquaculture sites. PLOS ONE 10:e0136772

* Salvo F, Hamoutene D, Dufour SC (2015b) Trophic analyses of opportunistic polychaetes (Ophryotrocha cyclops) at salmonid aquaculture sites. J Mar Biol Assoc UK 95: 713-722

Sanderson JC, Dring MJ, Davidson K, Kelly MS (2012) Culture, yield and bioremediation potential of Palmaria palmata (Linnaeus) Weber \& Mohr and Saccharina latissima (Linnaeus) C.E. Lane, C. Mayes, Druehl \& G.W. Saunders adjacent to fish farm cages in northwest Scotland. Aquaculture 354-355:128-135

Smaal AC (2002) European mussel cultivation along the Atlantic coast: production status, problems and perspectives. In: Vadstein O, Olsen Y (eds) Sustainable increase 
of marine harvesting: fundamental mechanisms and new concepts. Developments in hydrobiology, Vol 167. Springer, Dordrecht, p 89-98

Sokolova IM, Pörtner HO (2003) Metabolic plasticity and critical temperatures for aerobic scope in a eurythermal marine invertebrate (Littorina saxatilis, Gastropoda: Littorinidae) from different latitudes. J Exp Biol 206:195-207

Solórzano L (1969) Determination of ammonia in natural waters by the phenolhypochlorite method. Limnol Oceanogr 14:799-801

Strand Ø, Jansen HM, Jiang Z, Robinson SM (2019) Perspectives on bivalves providing regulating services in integrated multi-trophic aquaculture. In: Smaal AC, Ferreira JG, Grant J, Petersen JK, Strand Ø (eds) Goods and services of marine bivalves. Springer, Cham, p 209-230

Taranger GL, Karlsen Ø, Bannister RJ, Glover KA and others (2015) Risk assessment of the environmental impact of Norwegian Atlantic salmon farming. ICES J Mar Sci 72: 997-1021

Tsutsumi H, Montani S, Kobe H (2002) Bioremediation of organic matter loaded on the sediment in outdoor pools with a polychaete, Capitella sp. 1. Fish Sci 68:613-616

Tsutsumi H, Kinoshita K, Srithongouthai S, Sato A and others (2005) Treatment of the organically enriched sediment below the fish farm with the biological activ-

Editorial responsibility: Pablo Sánchez Jerez, Alicante, Spain ities of artificially mass-cultured colonies of a small deposit feeding polychaete, Capitella sp. I. Benthos Res 60:25-38

Valdemarsen T, Bannister RJ, Hansen PK, Holmer M, Ervik A (2012) Biogeochemical malfunctioning in sediments beneath a deep-water fish farm. Environ Pollut 170:15-25

* Valdemarsen T, Hansen PK, Ervik A, Bannister RJ (2015) Impact of deep-water fish farms on benthic macrofauna communities under different hydrodynamic conditions. Mar Pollut Bull 101:776-783

* Wang X, Olsen LM, Reitan KI, Olsen Y (2012) Discharge of nutrient wastes from salmon farms: environmental effects, and potential for integrated multi-trophic aquaculture. Aquacult Environ Interact 2:267-283

* Whiteley N, Rastrick S, Lunt D, Rock J (2011) Latitudinal variations in the physiology of marine gammarid amphipods. J Exp Mar Biol Ecol 400:70-77

*Wiklund H, Glover AG, Dahlgren TG (2009a) Three new species of Ophryotrocha (Annelida: Dorvilleidae) from a whale-fall in the North-East Atlantic. Zootaxa 2228: 43-56

*Wiklund H, Glover AG, Johannessen PJ, Dahlgren TG (2009b) Cryptic speciation at organic-rich marine habitats: a new bacteriovore annelid from whale-fall and fish farms in the North-East Atlantic. Zool J Linn Soc 155: $774-785$

Submitted: February 16, 2020; Accepted: July 10, 2020

Proofs received from author(s): August 30, 2020 